Claremont Colleges

Scholarship@ Claremont

All HMC Faculty Publications and Research

HMC Faculty Scholarship

$11-1-2005$

\title{
Proof Without Words: Alternating Sums of Odd Numbers
}

Arthur T. Benjamin

Harvey Mudd College

\section{Recommended Citation}

Benjamin, A.T. (2005). Proof without words: alternating sums of odd numbers. Mathematics Magazine, 78(5): 385.

This Article is brought to you for free and open access by the HMC Faculty Scholarship at Scholarship @ Claremont. It has been accepted for inclusion in All HMC Faculty Publications and Research by an authorized administrator of Scholarship @ Claremont. For more information, please contact scholarship@cuc.claremont.edu. 


\section{Proof Without Words: Alternating Sums of Odd Numbers}

$$
\sum_{k=1}^{n}(2 k-1)(-1)^{n-k}=n
$$

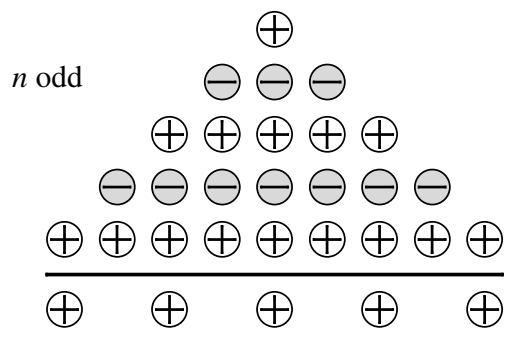

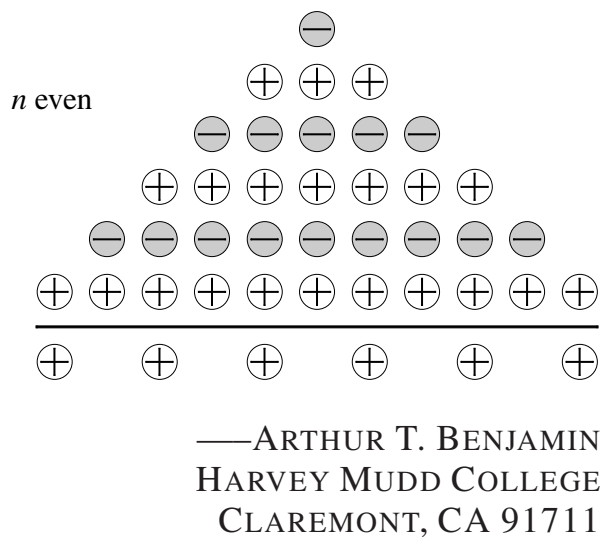

